\title{
The day digital information is no longer optional: A reflection on the COVID-19 pandemic
}

\author{
Hasanuddin Nuru ${ }^{1,2^{*}} \mathbb{D}$, Ardian Adhiwijaya ${ }^{3}$, and Fardiana Mamang ${ }^{4}$ \\ ${ }^{1}$ Faculty of Health Science, Dehasen University, Indonesia \\ 2 Training and Education Subdivision, Makassar City Hospital, Indonesia \\ ${ }^{3}$ Nursing Department, Faculty of Health Science, Alauddin State Islamic University, Makassar, Indonesia \\ ${ }^{4}$ Health Promotion Department, Public Health Center of Mamajang Regency, Makassar, Indonesia
}

Doi: https://dx.doi.org/10.36685/phi.v7i2.426

Received: 23 June 2021 | Accepted: 24 June 2021

Corresponding author:

Hasanuddin Nuru, S.Kep., Ns., M.Kes., Ph.D

Makassar City Hospital. Jl. P. Kemerdekaan KM 14

Biringkanaya, Makassar, Indonesia

Email: hasanuddinmu@gmail.com

Copyright: (c) 2021 the author(s). This is an open-access article distributed under the terms of the Creative Commons Attribution Non-Commercial License, which permits unrestricted non-commercial use, distribution, and reproduction in any medium provided the original work is properly cited.

Keywords: COVID-19; digital technology; augmented reality; health services

The COVID-19 pandemic is not over yet. It has changed many aspects of life, habits and routines, and the acceleration of information and technology. The acceleration of digital information intends to change and improve the entity of data, computing, communication, and connectivity technologies (Vial, 2019). Everything can be done that has never been done before. We can work from home, or we do not have to go to school to study. It is not essential to visit a market to find basic needs, and we can also provide health services over long distances. This is how digital transformation can reach everyone without meet up, and it can protect people from deadly diseases such as the COVID-19.

The pandemic has finally shown the important role of nurses in health services. The use of digital technology in nursing, both in education and practice, has been running and showing sound effects. Some of which have been running, such as the use of Virtual Reality (VR) to reduce pain in inpatients (Spiegel et al., 2019), approach using smartphones and applications for remote pain management of adolescent cancer patients (Jibb et al., 2017), and the use of augmented reality in nursing learning (Madden \& Carstensen, 2019). The use of digital technology is an opportunity that must not be missed by the nursing world, both in educational and clinical settings. Significantly as the largest component in health services, the use of technology in nursing services will positively impact overall health services, predominantly in the pandemic. However, this opportunity comes along with challenges. Indeed, policy and financial support have a major role in the development of nursing in the digital world (Booth et al., 2021).

In addition, the development of digital transformation is also crucially developing in the world of leadership. This process can change the way a person leads in an organization. Information technology through mobile devices provides an opportunity for anyone to get direct access to all types of information instantly (Schwarzmüller et al., 2018). The development of digital technology requires contemporary leaders to be skilled in information technology in order to improve their leadership skills and behavior which is undoubtedly different from a few years ago (Serban et al., 2015). Furthermore, various global economies are trying to 
implement new strategies by making new opportunities in digital transformation. This is the main focus on the impression of technological convergence and innovations that can increase creativity to benefit and enhance company performance (Ribeiro-Navarrete et al., 2021). Finally, digital transformation provides opportunities for many people to work independently from home. Therefore, it is recommended that everyone increase the creative idea and enhance innovation to protect us from the pandemic situation.

Declaration of Conflicting Interest

The authors declare no conflicts of interest.

Funding

None.

\section{Author Contributions}

All authors contributed equally to this study.

\section{Author Biographies}

Hasanuddin Nuru, S.Kep., Ns., M.Kes., PhD is a Lecturer at the Faculty of Health Science, Dehasen University, Indonesia. He is also assigned as an Acting Head of Nursing and Midwifery Department and a Head of Education and Training Department in RSUD Daya Kota Makassar, Indonesia.

Ardian Adhiwijaya, S. Kep. Ns., M. Kes is a Lecturer at the Faculty of Health Science, Alauddin State Islamic University, Makassar, Indonesia.

Fardiana Mamang, SKM., M.Kes is a Health Promotion Officer at the Public Health Center of Mamajang Regency, Makassar, Indonesia.

\section{References}

Booth, R. G., Strudwick, G., McBride, S., O’Connor, S., \& López, A. L. S. (2021). How the nursing profession should adapt for a digital future. British Medical Journal, 373. https://doi.org/10.1136/bmj.n1190

Jibb, L. A., Stevens, B. J., Nathan, P. C., Seto, E., Cafazzo, J. A., Johnston, D. L., . . Stinson, J. N. (2017). Implementation and preliminary effectiveness of a real-time pain management smartphone app for adolescents with cancer: A multicenter pilot clinical study. Pediatric Blood \& Cancer, 64(10), e26554. https://doi.org/10.1002/pbc.26554

Madden, K., \& Carstensen, C. (2019). Augmented reality in nursing education. Kai Tiaki: Nursing New Zealand, 25(5), 28-29.

Ribeiro-Navarrete, S., Botella-Carrubi, D., PalaciosMarqués, D., \& Orero-Blat, M. (2021). The effect of digitalization on business performance: An applied study of KIBS. Journal of Business Research, 126, 319-326. https://doi.org/10.1016/j.jbusres.2020.12.0 65

Schwarzmüller, T., Brosi, P., Duman, D., \& Welpe, I. M. (2018). How does the digital transformation affect organizations? Key themes of change in work design and leadership. Mrev Management Revue, 29(2), 114138. https://doi.org/10.5771/0935-9915-2018-2-114

Serban, A., Yammarino, F. J., Dionne, S. D., Kahai, S. S., Hao, C., McHugh, K. A., \& Peterson, D. R. (2015). Leadership emergence in co-located and virtual teams: A multilevel model with agent-based simulations, quasi-experimental and experimental tests. The Leadership Quarterly, 26, 402-418.

Spiegel, B., Fuller, G., Lopez, M., Dupuy, T., Noah, B., Howard, A., . . . Ahn, J. (2019). Virtual reality for management of pain in hospitalized patients: A randomized comparative effectiveness trial. Plos One, 14(8), e0219115. https://doi.org/10.1371/journal.pone. 0219115

Vial, G. (2019). Understanding digital transformation: A review and a research agenda. The Journal of Strategic Information Systems, 28(2), 118-144. https://doi.org/10.1016/j.jsis.2019.01.003

Cite this article as: Nuru, H., Adhiwijaya, A., \& Mamang, F. (2021). The day digital information is no longer optional: A reflection on the COVID-19 pandemic. Public Health of Indonesia, 7(2), 93-94. https://dx.doi.org/10.36685/phi.v7i2.426 